Primljen / Received: 23.10.2019 Ispravljen / Corrected: 16.10.2020

Prihvaćen / Accepted: 26.10.2020.

Dostupno online / Available online: 10.11.2020.

\section{Proposal of response spectra in the second generation of Eurocode EN 1998-1-1 for seismic areas and comparison with the existing standard EN 1998-1: 2004}

Authors:

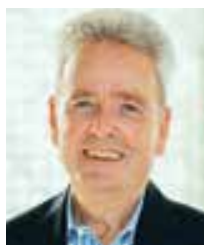

Prof.emeritus Mehmed Čaušević, PhD. CE.

University of Rijeka

Faculty of Civil Engineering

mcausevic@gradri.uniri.hr

Corresponding author

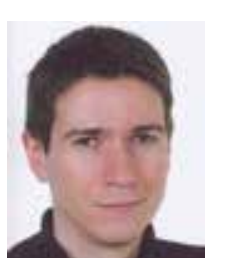

Assoc.Prof. Mladen Bulić, PhD. CE

University of Rijeka

Faculty of Civil Engineering

mbulic@gradri.uniri.hr

\section{Mehmed Čaušević, Mladen Bulić}

Proposal of response spectra in the second generation of Eurocode EN 1998-11 for seismic areas and comparison with the existing standard EN 1998-1: 2004

Fundamental changes of the existing standard EN 1998-1, with incorporation of latest research results, are proposed in the second generation of Eurocode EN 1998-1-1. A spectrum of earthquake loads, defined by several points established in a probabilistic manner, is presented and commented on. In addition, the new EN 1998-1-1: a) introduces 12 return periods for earthquakes (instead of the previous two periods), b) cancels previous elastic spectra Type 1 and Type 2, c) introduces a new moment magnitude Mw instead of the surface magnitude Ms, d) introduces four limit states instead of the previous two NCR and DLR, etc.

\section{Key words:}

Eurocode, seismic hazard, response spectrum, limit state, behaviour factor, nonlinear static method

Prethodno priopćenje

\section{Mehmed Čaušević, Mladen Bulić}

Prijedlog spektara odziva u drugoj generaciji Eurokoda EN1998-1-1 za seizmička područja i usporedba s postojećom normom EN 1998-1: 2004

U drugoj generaciji Eurokoda EN 1998-1-1 predlažu se korjenite izmjene postojeće norme EN 1998-1: 2004, koje sadrže rezultate najnovijih znanstvenih istraživanja. U radu se predstavlja i komentira novi spektar opterećenja od potresa, kojeg definira nekoliko točaka koje su ustanovljene na probabilistički način. U novom EN 1998-1-1 se: a) uvodi 12 povratnih razdoblja potresa (do sada su bila dva), b) ukidaju dosadašnji elastični spektri tipa 1 i tipa 2, c) uvodi nova momentna magnituda Mw umjesto površinske magnitude Ms, d) umjesto dosadašnja dva granična uvjeta NCR i DLR uvode se četiri; itd.

Ključne riječi:

eurokod, seizmički hazard, spektar odziva, granična stanja, faktor ponašanja, nelinearna statička metoda

Vorherige Mitteilung

\section{Mehmed Čaušević, Mladen Bulić}

Vorgeschlagenes Antwortspektrum in der zweiten Generation des Eurocodes EN19981-1 für seismische Gebiete und Vergleich mit der bestehenden Norm EN 1998-1:2004

Die zweite Generation des Eurocodes EN 1998-1-1 schlägtradikale Änderungen der bestehenden Norm EN 1998-1: 004 vor, die die Ergebnisse der neuesten wissenschaftlichen Forschung enthält. Die Arbeit präsentiert und kommentiert ein neues Spektrum von Erdbebenlasten, das durch mehrere Punkte definiert wird, die auf probabilistische Weise festgelegt wurden. Der neue EN 1998-1-1 führt außerdem 12 Rückkehrperioden von Erdbeben ein (bisher gab es zwei); die aktuellen elastischen Spektren von Typ 1 und Typ 2 werden abgeschafft; er führt eine neue Momentgröße Mw anstelle der Oberflächengröße Ms ein; anstelle der beiden vorhergehenden Randbedingungen NCR und DLR werden vier eingeführt; usw.

Schlüsselwörter:

Eurocode, Erdbebengefährdung, Antwortspektrum, Grenzzustände, Verhaltensfaktor, nichtlineare statische Methode 


\section{Introduction}

The need for regulating construction methodology in seismically active areas in Slovenia, Croatia, Serbia, Bosnia \& Herzegovina, Montenegro, and Northern Macedonia, has been recognised for a long time now. The history and development of construction regulations in seismically active areas of Slovenia and former Yugoslavia are described in [1, 2]. In effect, there were no special seismic regulations for construction work, nor was the seismic load properly defined, until 1964. Before that year, seismic load had only been mentioned in the definition of a minimum horizontal load imposed on structures. It is only after the 1963 Skopje earthquake that first regulations for the definition of seismic load, and for construction in seismic areas, came into force in the mentioned territories [3]. The regulation passed in 1964 remained valid until a subsequent regulation was passed in 1981 [4]. This regulation, based on new findings about seismic load and construction in seismic areas, was further elaborated on several occasions (in 1982, 1983, 1988 and 1990), and it remained in force until introduction of the European pre standard, which later became the European standard EN 1998. After 2011, the use of EN 1998 became mandatory in Croatia [5]. Development of international regulations on seismic load and construction in seismic area has been fully elaborated in [6] for buildings, with a special emphasis on future regulations. It should be noted that two above mentioned regulations (from 1964 [3] and 1981 [4]) were highly innovative for the time in which they were written, and that they brought considerable novelties as derived from research projects performed at that time worldwide in the field of earthquake engineering. The second generation of European standards is currently being prepared in the scope of the sub-committee SC8 (chaired by P. Bisch [7]) of the Tehnical Committee (TC) 250. The existing standard EN 1998-1:2004 is to be divided in the second generation of this standard into two parts: EN 1998-1-1 (which defines basic terms and seismic actions) and EN 1998-1-2 for buildings. The provisions given in EN19981-1, out of which only the most important - defining seismic loads imposed on structures -will be commented on in this paper. These comments are based on the last variant published on 12 September 2020, which serve as foundations for all parts of Eurocode 8 (for buildings, bridges, structural repairs, silos, tanks, foundation and supporting structures, cable-supported slender high-rise structures, and tall chimneys). It is important to point out that the mentioned second-generation standards define elastic and reduced response spectra in a way that completely differs from the way spectra are defined in the current first generation of this standard. A part of EN 1998-1-2 is related to buildings. It is optimistically expected that the second generation Eurocode 8 will be technically complete by the end of 2022, after which it is to be translated into official languages of the EU. Some provisions of the second-generation standard EN 19981-1, and some provision from EN 1998-1-2 for buildings, will be presented and commented on in this paper.

It will be significant for anyone involved in earthquake engineering the day when the new European structural standards will entry into force and bring crucial changes when compared to the current EN1998-1: 2004 standard. It is therefore important for all involved to be informed gradually and timely about these significant novelties. It is known that structural European standards are scientifically based and that, for their proper understanding, a sufficient background knowledge must be gained, mostly through university studies, and education focused on earthquake engineering, structural dynamics, and stability of structures. The fact that no additions or changes to the existing standard EN 1998-1: 2004 have been made, and that a fully new standard EN 1998-1-1 and EN 1998-1-2 has been proposed instead, clearly points to the significance of changes that have been made to the existing standard. The most significant changes are:

- Maps showing seismic hazard for each location at a given territory are prescribed, and earthquake return periods are defined with two parameters: selected limit state (LS) and selected consequence class (CC) for buildings. Twelve earthquake return periods are introduced (instead of two that are currently in use), which means that, as a rule, twenty-four maps should be made (12 return periods, each with two spectral ordinates $S$ and $S_{\beta}$ that will be introduced and explained below in Section 3.2). Two maps should be made as a minimum, because multiplication factors can be used.

- It should be noted that the approach based on the use of multiplication factors is suboptimal, and is oftentimes overly conservative.

- In the second-generation EN 1998-1-1, the load spectrum is fixed with several points that are determined probabilistically (other spectrum points are defined deterministically), and these points are: spectral values "on plateau", for $T=1 \mathrm{~s}$ and for $T=T_{A}$. This spectrum has been modernized with respect to the spectrum given in the current EN 1998-1: 2004, as several points in this new spectrum are defined based on the probabilistic approach, while in the existing spectrum EN 1998-1: 2004 only one point (for $\mathrm{T}=0$ ) is defined probabilistically. This means that the seismic input scaling is no longer PGA (Peak Ground Acceleration) as in EN 1998-1: 2004 but rather two spectral ordinates, $S$ and $S$, are introduced instead of PGA.

- Current Type 1 and Type 2 elastic spectra are to be abolished. A new moment magnitude $M_{w}$ is introduced instead of the surface magnitude $M_{s}$. The moment magnitude $M_{w}$ is defined in the literature (its simplified explanation is given in [9]).

- The following four limit states are introduced instead of the current two limit states (NCR and DLR): near-collapse (NC), significant damage (SD), damage limitation (DL) and fully operational (OP).

- The behaviour factor concept $q$ is used in all modern regulations worldwide (although it is marked $R$ in some countries) and so the concept of $q$ factor has been kept in the second generation EN19981-1, but behaviour factors are now defined in a different way.

The above notions will be presented and commented later in this paper. The objective of this paper is to gradually inform anyone involved in earthquake engineering, and who use the Eurocode EN 1998-1: 2004, about significant changes that are being made to this standard in the second generation of its application. The paper is written to point to crucial changes that are being made to the existing standard with regard to the definition of structural load (response spectrum). 


\section{Eurocode 8, Part 1-1: Fundamental design requirements}

\subsection{Safety principles}

New terms introduced in EN 1998-1-1 will be considered below. In case of an earthquake event, the design of structures is based on the well-known "performance-based concept" [12]. So, the following principles have been adopted in EN 1998-11: Structures must be seismically designed in such a way that, in case of an earthquake event, human lives are protected, the scope of seismic damage is limited, and significant structures remain operational immediately after an earthquake event.

The achievement of these objectives is measurable in a probabilistic sense, and the goal of EN 1998-1-1 is to limit consequences of seismic events. Seismic actions are considered conventional cases of load, and are characterised by their return periods.

In order to achieve the above-mentioned objectives, it is specified in EN 1998-1-1 that structures should be designed in such a way that specified limit states (LS) will not be exceeded in the case of occurrence of some specified seismic actions. That is why four limit states are introduced:

- near collapse (NC),

- significant damage (SD) - the fulfilment of this requirement is obligatory,

- damage limitation (DL),

- fully operational (OP), which is applied for the third consequence class (CC3), Table 1.

Table 1. Definitions of consequence classes CC3-a and CC3-b for buildings

\begin{tabular}{|c|l|}
\hline CC3-a & $\begin{array}{l}\text { Buildings whose seismic resistance is important in view } \\
\text { of the consequences associated with the collapse, e.g. } \\
\text { schools, assembly halls, cultural institutions, etc. }\end{array}$ \\
\hline CC3-b & $\begin{array}{l}\text { Buildings whose integrity during earthquakes is of vital } \\
\text { importance for civil protection, e.g. hospitals, fire stations, } \\
\text { power plants, etc. and their equipment }\end{array}$ \\
\hline
\end{tabular}

There are only two limit states in the current standard [5]: near collapse requirement (NCR) and damage limitation requirement (DLR).

It is specified in EN 1998-1-1 that requirements must be fulfilled for most new buildings in the case of significant damage (SD), and that the near collapse (NC) requirement should not be exceeded for some specified seismic event and for some types of buildings depending on their significance.

The fulfilment of requirements with regard to specific structural properties is achieved through selection of appropriate return periods $\left(T_{L S, C C}\right)$ related to appropriate limit states (LS), and depending on the consequence class (CC) of the structure under consideration, Table 2. As an alternative to return periods, it is also possible to use performance factors $\left(\gamma_{L S, C C}\right)$ by which seismic forces are multiplied, Table 3.

Unless specified otherwise by a National annex of each EU country, the 475 year return period is related to the limit state
SD for structures with $\mathrm{CC} 2$, in which case the corresponding value of the performance factor $\gamma_{\mathrm{SD}, \mathrm{CC} 2}$ is 1 . Longer return periods or greater performance factors would be related to the limit state of near collapse (NC) and to the consequence class CC3.

Table 2. Return periods of seismic action $T_{L S, C C}$ (in years)Tablica 3.

\begin{tabular}{|c|c|c|c|c|}
\hline \multirow{2}{*}{$\begin{array}{c}\text { Limit state } \\
\text { (LS) }\end{array}$} & \multicolumn{4}{|c|}{ Consequence class CC } \\
\cline { 2 - 5 } & CC1 & CC2 & CC3-a & CC3-b \\
\hline NC & 800 & 1600 & 2500 & 5000 \\
\hline SD & 250 & 475 & 800 & 1600 \\
\hline DL & 50 & 60 & 60 & 100 \\
\hline
\end{tabular}

Table 3. Performance factors $\gamma_{L S, C C}$

\begin{tabular}{|c|c|c|c|c|}
\hline \multirow{2}{*}{$\begin{array}{c}\text { Limit state } \\
\text { (LS) }\end{array}$} & \multicolumn{4}{|c|}{ Consequence class CC } \\
\cline { 2 - 5 } & CC1 & CC2 & CC3-a & CC3-b \\
\hline NC & 1.2 & 1.5 & 1.8 & 2.2 \\
\hline SD & 0.8 & 1 & 1.2 & 1.5 \\
\hline DL & 0.4 & 0.5 & 0.5 & 0.6 \\
\hline
\end{tabular}

Twelve distinct return periods can be seen in Table 2 and Table 3. Performance factors $\gamma_{L S, C C}$, are used as correction factors when deciding how many seismic hazard maps should be adopted at the level of individual EU country.

As 12 distinct return periods are specified, the following questions can be asked: Will new maps be made with the return periods other than 475 years

- Will new maps be made with the return periods other than 475 years, or will this be solved by introducing the performance factors? Each EU country must solve this dilemma for itself. Here we can see the significance of introducing performance factors $\left(\gamma_{L S, C C}\right)$.

- The existing map in current standard EN 1998-1: 2004 for the return period of 475 years was prepared taking into account the surface magnitude $M_{s}$ whereas in the second generation EN 1998-1-1 the moment magnitude $M_{w}$ is introduced. What are the consequences of this new introduction?

The difference between the spectrum value for $T_{A}$ (earlier: PGA) and $S_{\alpha}$ "on plateau" is approximately 2.5 . This brings up the following question: can the new maps for $S_{\alpha}$ be obtained from the existing map according to the currently valid EU 1998-1: 2004 by multiplying the values from that existing map with the factor of 2.5 ? The answer to this question is expected from the seismologists [8].

So, the current Type 1 and Type 2 elastic spectra will be abolished, which is a great relief, as the Type 1 and Type 2 spectra have caused confusion in the professional and research communities. The introduction of $M_{w}$ will not cause any significant changes in practical application of the second-generation EN 1998-1-1. In the opinion of seismologists [8], the surface magnitude $M_{s}$ has in any case been wrongly introduced. The moment magnitude $M_{w}$ establishes a relationship between the earthquake strength and released 
energy, taking into account the sliding in the fault and the value of surface along which the sliding occurs (for instance: $M_{w}=8,8$ for the catastrophic earthquake that hit Chile on 27 March 2010) [9].

The map with the return period of 95 years is not specified at all in the second-generation EN 1998-1-1.

\subsection{Principles of structural design according to second-generation EN 1998-1-1}

It is specified in EN 1998-1-1 that requirements for the design of structures must be based of the behaviour of structures during earthquake, which is defined through a combination or resistance, deformation capacity, and total energy-dissipation capacity. The factor $\alpha_{\mathrm{u}} / \alpha_{1}$ [5], derived from the use of other relevant European standards, is also taken into account.

Two approaches are generally used in order to verify the combination of resistance, deformation capacity, and cumulative energy-dissipation capacity: approach based on forces, and approach based on displacements.

It is specified in the current EN 1998-1: 2004 that the deformation capacity and cumulative energy-dissipation capacity are achieved through implementation of the capacity design procedure. It has led to the situation in which structures are categorised into three classes of ductility: DCL (low level of ductility), DCM (medium level of ductility) and DCH (high level of ductility), based on harmonisation with provisions specified in an appropriate part of EN 1998-1: 2004.

Three ductility classes (DC1, DC2 and DC3) are defined in the second-generation EN 1998-1-1, but in a different way in comparison to current EN 1998-1: 2004. Class DC1 corresponds to the calculation without considering the material the structure is made of. This is equivalent to class DCL in EN1998-1: 2004. The capacity factor is taken into account in DC1, but the deformation capacity and energy-dissipation capacity are neglected.

The calculation according to class DC2 is conducted using the same rules as for the calculation of wind action or self-weight. It is however assumed that the behaviour factor $q$ is equal to 2 or more, which is dependent on some appropriate details in combination with ensuring appropriate ductility.

Structural provisions for structural systems that are not included in EN 1998-1: 2004 are now introduced. These provisions are flat concrete slabs, bracing against buckling, and connections through which dissipation of seismic energy is ensured.
DC2 takes into account local deformation capacity and local energydissipation capacity. The control of global plastic mechanisms is ensured by limiting relative displacements and second-order effects. DC3 takes into account capacity of the structure to form global plastic mechanisms at the limit state SD, i.e. to form its local capacity, local deformation capacity and local energy-dissipation capacity. It can be stated that the ductility class DCH from the current standard is more difficult to achieve with regard to details and fulfilment of requirements for this ductility class, as compared to DC3 in the second generation of this standard.

Specific rules for timber structures have been modernised based on appropriate research results. Rules for masonry buildings, which are characterized by a significant number of nationally defined parameters, are better harmonised. The part relating to aluminium structures has been introduced. In addition, rules for partition and facade walls have been improved.

\section{Eurocode 8, Part 1-1: ground classification and seismic forces}

\subsection{Ground classification}

Before proceeding to definition of seismic forces, it is necessary to identify conditions at the location where the building is situated. This section briefly describes the way in which this identification is made in EN 1998-1-1.

In order to categorise the site of the building, it is necessary to determine the type of material that is situated below the building foundations at the depth of no less than $30 \mathrm{~m}$, except in cases where rock formation is situated at smaller depths. In other words, for each building location, it is first necessary to determine the depth at which hard material (rock) is situated. The shear wave velocity profile $v_{s}$ in soil is considered the most reliable anticipator of seismic action properties at stable locations.

Except in special cases when soil at the location of a structure is not stable, the standard site categorisation (categories $A$ through $\mathrm{F}$ ) is based on the following two parameters (Table 4):

- $\mathrm{H}_{800}$ depth of hard material (such as rock) that is identified for the case when the shear wave propagation velocity $v_{s}$ exceeds $800 \mathrm{~m} / \mathrm{s}$,

- $v_{s, \mathrm{H}}$, average shear wave velocity down to the depth $\mathrm{H} ; \mathrm{H}$ is assumed to be $30 \mathrm{~m}$ if $\mathrm{H}_{800}>30 \mathrm{~m}$, in which case $v_{s, H}$ is marked as $v_{\mathrm{s}, 30} ; \mathrm{H}=\mathrm{H}_{800}$, if $\mathrm{H}_{800}<30 \mathrm{~m}$.

Table 4. Standard site categorisation

\begin{tabular}{|c|c|c|c|c|}
\hline \multirow{2}{*}{ Depth class } & Ground class & Stiff & Medium stiffness & Soft \\
\hline & $\mathrm{H}_{800} \mathrm{v}_{s, \mathrm{H}}$ & $400 \mathrm{~m} / \mathrm{s} \leq v_{s, H}<800 \mathrm{~m} / \mathrm{s}$ & $250 \mathrm{~m} / \mathrm{s} \leq v_{s, H}<400 \mathrm{~m} / \mathrm{s}$ & $150 \mathrm{~m} / \mathrm{s} \leq v_{s, H}<250 \mathrm{~m} / \mathrm{s}$ \\
\hline Very shallow & $\mathrm{H}_{800} \leq 5 \mathrm{~m}$ & A & A & $E$ \\
\hline Shallow & $5 \mathrm{~m}<\mathrm{H}_{800} \leq 30 \mathrm{~m}$ & B & E & E \\
\hline Intermediate & $30 m<H_{800} \leq 100 m$ & B & C & D \\
\hline Deep & $\mathrm{H}_{800}>100 \mathrm{~m}$ & B & $\mathrm{F}$ & $\mathrm{F}$ \\
\hline
\end{tabular}


$v_{s, H}$ is obtained by measurement (using available measurement techniques) of the shear wave velocity $v_{i}$ in each soil layer "i" the height of which $h_{i}$ is obtained using the following relation (1), where $\mathrm{N}$ is the total number of soil layers from the ground surface down to the depth $\mathrm{H}$.

$v_{s, H}=\frac{H}{\sum_{i=1}^{N} \frac{h_{i}}{v_{i}}}$

An alternative to the determination of $\mathrm{H}_{800}$ and $v_{\mathrm{s}, \mathrm{H}}$ by shear wave velocity measurements is to use a simplified procedure for identifying building/structure location categories, which is described in annex A to EN 1998-1-1.

\subsection{Response spectra and seismic forces}

The reference seismic hazard in EN 1998-1-1 is described using the following two parameters, Figure 1:

- $S_{\alpha, r e f}$ is the comparative maximum spectral acceleration that corresponds to the acceleration "on plateau" of the elastic response spectrum (Figure 1) with $5 \%$ damping, at the category $A$ building location, for the return period of $T_{r e f}=$ $T_{S D, C C 2^{\prime}}$

- $S_{\beta, r e f}$ is the comparative spectral acceleration of the vibration period $T_{\beta}=1 \mathrm{~s}$, with $5 \%$ damping, at the category A terrain, for the return period of $T_{r e f}=T_{S D, C C 2}$.

$T_{\text {ref }}$ is 475 years (and is named as the SD return period), unless otherwise stated in the National annex and $\eta$ is the correction factor for damping.

Seismologists will define these $S_{\alpha, \text { ref }}$ and $S_{\beta, \text { ref }}$ parameters and will prepare national hazard maps for each earthquake return period.

To simplify, $S_{\beta, \text { ref }}$ can be determined from $S_{\alpha, r e f}$ using the following equation (2):

$S_{\beta, \text { ref }}=f_{h} \cdot S_{\alpha, \text { ref }}$

In equation (2), $f_{\mathrm{h}} \sim 0.2$ for low level of seismicity, $f_{\mathrm{h}} \sim 0.3$ for moderate level of seismicity, and $f_{\mathrm{h}} \sim 0.4$ for high level of seismicity.

Seismicity levels are presented on national maps based on the comparative spectral acceleration value in soil for the category A location, and comparative return period of 475 years, $S_{\alpha, 475}$ : (very low: $S_{\alpha, 475}<1.0 \mathrm{~m} / \mathrm{s}^{2}$; low: $S_{\alpha, 475}$ between 1.0 and $2.5 \mathrm{~m} /$ $\mathrm{s}^{2}$; moderate: $S_{\alpha, 475}$ between 2.5 and $5.0 \mathrm{~m} / \mathrm{s}^{2}$; high: $S_{\alpha, 475}>5.0$ $\mathrm{m} / \mathrm{s}^{2}$ ).

$S_{\alpha, 475}(T)$ is the comparative maximum spectral acceleration that corresponds to the acceleration "on plateau" of elastic response spectrum with $5 \%$ of relative damping, at category A location, for moderate level of seismicity $S_{\alpha}=3$ $\left.\mathrm{m} / \mathrm{s}^{2}\right)$ and high level of seismicity $\left(S_{\alpha}=7.5 \mathrm{~m} / \mathrm{s}^{2}\right)$ [10].

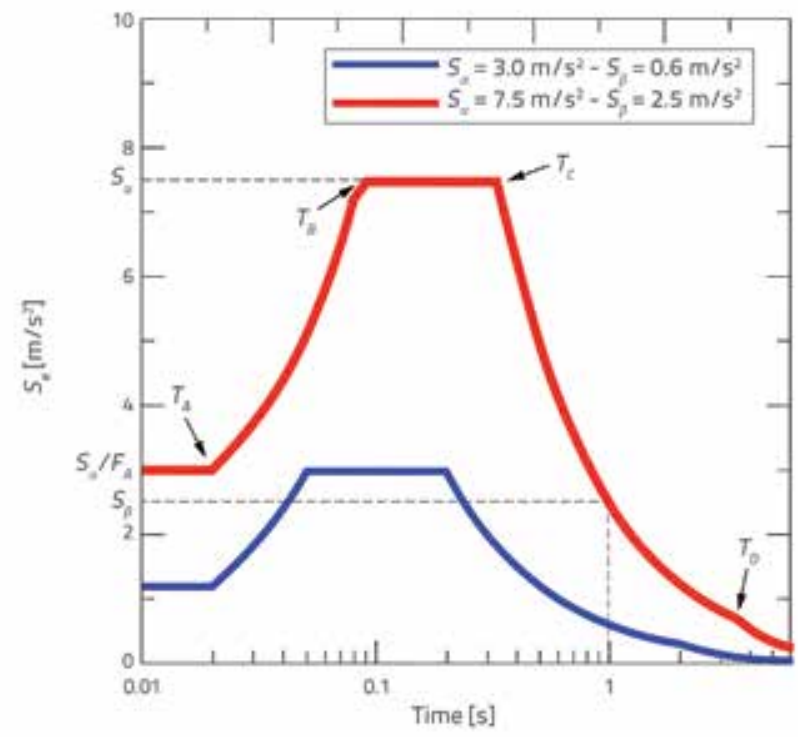

Figure 1. Elastic response spectrum for site category $A$, and two different pairs ( $S_{\alpha}, S_{\beta}$ ) for two levels of seismicity: ( $S_{\alpha}=\mathbf{3}$ $\left.\mathrm{m} / \mathrm{s}^{2}\right)$ blue and $\left(S_{\alpha}=7.5 \mathrm{~m} / \mathrm{s}^{2}\right)$ red, at horizontal logarithmic scale[10]

If it is necessary to determine a comparative seismic hazard for the location with the category different from category $A$ and for the return period RP different from 475 years, and related to limit states different from the limit state SD. Also, for an arbitrary consequence class CC, the corresponding values of parameters $S_{\alpha, R P}$ and $S_{\beta, R P}$ can be obtained using the performance factors $\gamma_{L S, C C}$ from Table 3 as follows:

$S_{\alpha, R P}=\gamma_{L S, C C} \cdot S_{\alpha, r e f}$

$S_{\beta, R P}=\gamma_{L S, C C} \cdot S_{\beta, \text { ref }}$

If the comparative seismic hazard is to be determined for the location different from location $A$, and if there are no special seismic hazard studies for the location under study, then the spectrum is defined by including additional parameters the values of which are given in Table 5 and Table 6.

Table 5. Values of parameters defining the standard elastic response spectrum

\begin{tabular}{|c|c|c|c|}
\hline$T_{A}[\mathrm{~s}]$ & $\chi$ & $F_{A}$ & $T_{D}[\mathrm{~s}]$ \\
\hline \multirow{2}{*}{0.02} & 4 & 2.5 & 2, if $\mathrm{S}_{\beta, \mathrm{RP}} \leq 1 \mathrm{~m} / \mathrm{s}^{2}$ \\
\cline { 4 - 4 } & & & $1+\mathrm{S}_{\beta, \mathrm{RP}}$, if $\mathrm{S}_{\beta, \mathrm{RP}}>1 \mathrm{~m} / \mathrm{s}^{2}$ \\
\hline
\end{tabular}

- $T_{A}$ is the short-period cut-off associated to the zero-period spectral acceleration, Figure 1,

- $T_{D}$ is the corner period at the beginning of the constant displacement branch $S_{\mathrm{de}}$ Figure 1 [9].

- $F_{A}$ is the reduction factor to get the zero-period spectral acceleration from $S_{\alpha^{\prime}}$ 
- controls $T_{B}$ "on plateau" of elastic spectrum, Figure 1, using the relation:

$$
\begin{aligned}
& T_{B}=\frac{T_{C}}{\chi}, \quad \text { if } \quad 0,05 \mathrm{~s} \leq \frac{T_{C}}{\chi} \leq 0.10 \mathrm{~s} \\
& T_{B}=0,05 \mathrm{~s}, \text { if } \quad \frac{T_{C}}{\chi}<0.05 \mathrm{~s} \\
& T_{B}=0,10 \mathrm{~s}, \text { if } \quad \frac{T_{C}}{\chi}>0.10 \mathrm{~s} \\
& T_{C}=\frac{S_{\beta} T_{\beta}}{S_{\alpha}}
\end{aligned}
$$$$
T_{B} \leq T \leq T_{C}: S_{e}(T)=\eta S_{\alpha}
$$$$
T_{C} \leq T \leq T_{D}: S_{e}(T)=\eta \frac{S_{\beta} T_{\beta}}{T}
$$$$
\text { (6) } \quad T \geq T_{D}: \quad S_{e}(T)=\eta T_{D} \frac{S_{\beta} T_{\beta}}{T^{2}}
$$

Spectral accelerations $S_{\alpha}$ and $S_{\beta}$ are obtained from equations (7) and (8),

$S_{\alpha}=F_{T} \cdot F_{\alpha} \cdot S_{\alpha, R P}$

$S_{\beta}=F_{T} \cdot F_{\beta} \cdot S_{\beta, R P}$

where:

$F_{\alpha}$ - is the short period site amplification factor, Table 6,

$F_{\beta}^{\alpha}$ - is the intermediate period ( $T=T_{\beta}=1 \mathrm{~s}$ ) site amplification factor, Table 6,

$F_{T}$ - is the topography amplification factor, which will not be presented in this paper.

Values of site amplification factors $F_{\alpha}$ and $F_{\beta}$ are given in Table 6 and are valid regardless of whether $v_{s, H}$ and $\mathrm{H}_{800}$ are defined by on-site measurements or an alternative simplified procedure (given in Annex A of EN 1998-1-1) is applied.

For the horizontal component of seismic action, the elastic response spectrum $S_{e}(T)$ should be defined deterministically using expressions (9) through (13):

$0 \leq T \leq T_{A}: \quad S_{e}(T)=\frac{S_{\alpha}}{F_{A}}$
The following terms are used in (9) to (13) (summary of terms that have been introduced):

$S_{\alpha}$ - is the maximum acceleration of response spectrum with $5 \%$ of relative damping "on plateau" according to equation (7)

$S_{\beta}$ - is acceleration in response spectrum for the vibration period $T=T_{\beta}$ according to equation (8), $T=T_{\beta}=1 \mathrm{~s}$

$T_{c}$ - is the right-side point "on plateau" of constant spectral acceleration, $T_{C}=\left(S_{\beta} T_{\beta}\right) / S_{\alpha^{\prime}}$ Figure 1

$T_{D}$ - is the value of the period from which starts the area of constant elastic displacement values $S_{\mathrm{de}^{\prime}}$ Figure 1.

Equations for elastic vertical response spectrum $S_{v e}(T)$ are also given in EN 1998-1-1.

\section{Eurocode 8, Part 1-1: Modelling, analysis and verification of structures}

\subsection{General explanations}

EN 1998-1-1 specifies parameters that are indispensable for all

\begin{tabular}{|c|c|c|c|c|}
\hline \multirow{2}{*}{$\begin{array}{l}\text { Site } \\
\text { category }\end{array}$} & \multicolumn{2}{|c|}{$\mathbf{F}_{\alpha}$} & \multicolumn{2}{|c|}{$\mathbf{F}_{\beta}$} \\
\hline & $\mathrm{H}_{800}$ and $\mathrm{v}_{\mathrm{s.H}}$ available & Default value & $\mathrm{H}_{800}$ and $\mathrm{v}_{\mathrm{s} . \mathrm{H}}$ available & Default value \\
\hline A & 1.0 & 1.0 & 1.0 & 1.0 \\
\hline B & \multirow{3}{*}{$\left(\frac{v_{S, H}}{800}\right)^{-0.40 r_{\alpha}}$} & $1.3\left(1-0.01 S_{\alpha . R P}\right)$ & \multirow{3}{*}{$\left(\frac{v_{S, H}}{800}\right)^{-0.70 r_{\beta}}$} & $1.6\left(1-0.02 S_{\beta . R P}\right)$ \\
\hline C & & $1.6\left(1-0.02 S_{\alpha . R P}\right)$ & & $2.3\left(1-0.03 S_{\beta . R P}\right)$ \\
\hline D & & $1.8\left(1-0.04 S_{\alpha . R P}\right)$ & & $3.2\left(1-0.10 S_{\beta . R P}\right)$ \\
\hline E & $\left(\frac{V_{s, H}}{800}\right)^{-0.40 r_{\alpha} \frac{H}{30}\left(4-\frac{H}{10}\right)}$ & $2.2\left(1-0.05 S_{\alpha . R P}\right)$ & $\left(\frac{v_{S, H}}{800}\right)^{-0.70 r_{\beta} \frac{H}{30}}$ & $3.2\left(1-0.10 S_{\beta . R P}\right)$ \\
\hline $\mathbf{F}$ & $0.90\left(\frac{v_{s, H}}{800}\right)^{-0.40 r_{\alpha}}$ & $1.7\left(1-0.04 S_{\alpha . R P}\right)$ & $1.25\left(\frac{v_{S, H}}{800}\right)^{-0.70 r_{\beta}}$ & $4.0\left(1-0.10 S_{\beta . R P}\right)$ \\
\hline & & $1-15 \frac{S_{\alpha, R P}}{V_{S, H}}$ & $\frac{R P}{H}$ & \\
\hline
\end{tabular}
parts of EN1998, i.e. for all types of structures, while provisions that are related to buildings only are given in EN 1998-1-2. Two

Table 6. Site amplification factors $F_{\alpha}$ and $F_{\beta}$ for the standard site categories of Table $4\left(S_{\alpha, R P}\right.$ and $\left.S_{\beta, R P}\left[\mathrm{~m} / \mathrm{s}^{2}\right], v_{\mathrm{s}, \mathrm{H}}[\mathrm{m} / \mathrm{s}]\right)$ 
Table 7. Default values of the behaviour factors $q_{R}$ and $q_{D}$ for horizontal seismic action and for ductility classes DC2 and DC3 for buildings

\begin{tabular}{|c|c|c|c|c|c|c|}
\hline \multirow{2}{*}{\multicolumn{2}{|c|}{ Structural type }} & \multirow{2}{*}{$\mathbf{q}_{\mathrm{R}}$} & \multicolumn{2}{|c|}{$q_{D}$} & \multicolumn{2}{|c|}{$q=q_{R} \cdot q_{S} \cdot q_{D}$} \\
\hline & & & DC2 & DC3 & DC2 & DC3 \\
\hline \multirow{3}{*}{$\begin{array}{l}\text { Moment resisting frame } \\
\text { or moment resisting } \\
\text { frame-equivalent dual } \\
\text { structures }\end{array}$} & $\begin{array}{l}\text { multi-storey. multi-bay moment resisting frames or } \\
\text { moment resisting frame-equivalent dual structures }\end{array}$ & 1.3 & \multirow{3}{*}{1.3} & \multirow{3}{*}{2.0} & 2.5 & 3.9 \\
\hline & multi-storey. one-bay moment resisting frames & 1.2 & & & 2.3 & 3.6 \\
\hline & one-storey moment resisting frames & 1.1 & & & 2.1 & 3.3 \\
\hline \multirow{4}{*}{$\begin{array}{l}\text { Wall- or wall-equivalent } \\
\text { dual structures }\end{array}$} & wall-equivalent dual structures & 1.2 & 1.3 & \multirow{3}{*}{2.0} & 2.3 & 3.6 \\
\hline & coupled walls structures & 1.2 & 1.4 & & 2.5 & 3.6 \\
\hline & uncoupled walls structures & 1.0 & 1.3 & & 2.0 & 3.0 \\
\hline & large walls structures & -- & \multicolumn{2}{|c|}{--} & \multicolumn{2}{|c|}{$3.0 k_{w}$} \\
\hline \multicolumn{2}{|l|}{ Flat slab structures } & 1.1 & 1.2 & - - & 2.0 & - - \\
\hline
\end{tabular}

approaches to the analysis of structures are introduced in EN 1998-1-1:

- The force-based approach, which is applied in two procedures: (a) using the equivalent lateral static action based on the behaviour factor $q$, and (b) modal analysis using response spectra;

- The displacement-based approach is also applied in two procedures: (a) nonlinear static analysis based on pushover method, and (b) nonlinear dynamic time-history analysis.

The use of the first approach is not allowed for verification of NC limit state.

\subsection{Seismic load based on reduced spectrum}

\subsubsection{Reduced spectrum $\mathrm{Sr}(\mathrm{T})$ according to the force- based approach}

First, it should be noticed that the term design spectrum from the existing standard EN 1998-1:2004 has been discarded, and that a new term, reduced spectrum, marked $S_{r}(T)$ is introduced. In this force-based approach, seismic action on structure is obtained from the reduced spectrum, established from the elastic response spectrum (Figure 1) using the behaviour factor $q$, which introduces deformation capacity and energy dissipation in the structure, and is expressed using the following equation:

$q=q_{R} \cdot q_{S} \cdot q_{D}$

$q_{R}$ is behaviour factor component accounting for "overstrength" due to the redistribution of seismic action effects in redundant structures; $q_{R}$ values for buildings are:

$q_{R}=\frac{\alpha_{u}}{\alpha_{1}}$

where:

- $\quad \alpha_{u}$ is the parameter by which horizontal seismic forces are multiplied so that these forces can attain the values at which a specified number of cross sections will achieve full plasticization, i.e. at which point the structure will become unstable (kinematical unstable mechanism);

- $\alpha_{1}$ is the parameter by which horizontal seismic forces are multiplied (at that, all other design forces are to remain unchanged), so that these forces can attain the values at which one of the least favourably load-affected cross sections of the structure will achieve full plasticisation.

For structures of the buildings that are torsional flexible, it should be assumed that $q_{R}$ is equal to 1 . The following applies to the behavior factors $q_{S}$ and $q_{D}$ :

$q_{s}$ - is behaviour factor component that originates from the reserves in the structure coming from other sources (such as reserves in bearing capacity of concrete and steel). The value of $q_{s}$ must not be greater than 1.5.

$q_{D}$ - is behaviour factor component accounting for the deformation capacity and energy dissipation capacity.

$q_{D}$ - for DC1, while other values, which are controlled by the ductility classes (DCM or DCH), should be selected so as to keep the necessary margin with respect to the NC deformation capacity.

To account for the prevailing failure mode in large walls structures, the behaviour factor $q$ should be calculated taking into consideration the factor, Table 7. The factor is determined in the similar way as defined in the current EN 1998-1 [5], taking into account the prevailing aspect ratio (height-to-length ratio) of the walls of the structural system. Reduced spectrum $S_{r}(T)$ is derived from equation (15):

$S_{r}(T)=\frac{S_{e}(T)}{R_{q}} \geq \beta S_{\alpha, 475}(T)$

The following is valid in this equation:

$$
\begin{array}{ll}
0 \leq T \leq T_{\mathrm{A}} & R_{q}(T)=R_{\mathrm{q} 0} \\
T_{A} \leq T \leq T_{B} & R_{q}(T)=R_{q 0}+\left(q-R_{q 0}\right)\left(T-T_{A}\right) /\left(T_{B}-T_{A}\right) \\
T_{B} \leq T & R_{q}(T)=q
\end{array}
$$


$R_{q}=q_{R} q_{S}$

where:

$q$ - behaviour factor defined by equation (14),

$\beta$ - bottom value of the boundary factor for horizontal reduced spectrum (applied for definition of forces only, and defined in national annex).

$S_{e}(T), T_{A^{\prime}} T_{B}$ - are defined by equations (9) to (13) for $\eta=1$ (relative damping $=5 \%$ ).

The reduced spectrum of vertical response $S_{v r}(T)$ is also defined in EN1998-1-1. The mark $R_{q}$ for definition of reduced spectrum has been introduced following the example of American regulations in which this value is named as the response modification coefficient $R$ and is dependent on the type of statictural system and the type of material [11].

\subsection{The force-based approach}

\subsubsection{Lateral force method}

Just like the first generation of Eurocode EN 1998-1:2004, the second generation EN 1998-1-1 also allows calculation of structures subjected to earthquakes by means of equivalent lateral static load in all three main directions, provided that the share of higher modes is negligible, i.e. that only the fundamental mode influence is taken into account.

As to this lateral force method, it is specified in EN 1998-1-1 that calculated displacements should be increased by adding the $q$ factor, and even by adding a greater value (without exceeding $3 q$ ) in the case the first natural frequency of the structure is lower than $T_{c}$ The influence of torsion must also be taken into account during definition of displacements.

\subsubsection{Modal response spectrum analysis}

This method should be applied in the case of structures that do not meet requirements for the application of the lateral force method, i.e. in the case when responses of higher vibration modes greatly contribute to the global response of the structure. The number of these modes is defined until the sum of their effective modal masses attains at least $90 \%$ of the total mass of the structural model, provided that the period of the last mode that is taken into account is greater than $T_{A}$.

\section{Combinations of modal responses:}

Responses in mode $i$ and mode $j$ (including also translational and torsional modes) can be assumed independent from one another if their periods $T_{i}$ and $T_{j}\left(T_{i} \geq T_{j}\right)$ and relative damping $\xi_{r}, \xi_{j}$ meet requirement which is given in equation (20).

$\left|T_{i}-T_{j}\right| /\left(T_{i}+T_{j}\right)>\xi_{i}+\xi_{j}$

When all relevant modal responses can be considered as independent from one another, the maximum value $E_{E}$ of the seismic action effect can be defined as shown in equation (21):

$E_{E}=\sqrt{\sum E_{E_{i}}^{2}}$

where:

$E_{E}$ - effect of seismic action considered (force, displacement, etc.),

$E_{E i}$ - effect of seismic action for mode $i$.

For any two modes $i$ and $j$ that fail to meet the requirement (20), the maximum response value is obtained by using equation (22), which is called CQC [9].

$E_{E}=\sqrt{\sum_{i} \sum_{j} E_{E i} r_{i j} E_{E j}}$

$r_{i j}$ is the correlation factor and is defined as follows (23) and (24):

if: $\xi_{i}=\xi_{j}=\xi: \quad r_{i j}=\frac{1}{1+\left(\frac{\alpha_{i j}}{\xi}\right)^{2}}, \alpha_{i j}=\frac{T_{i}-T_{j}}{T_{i}+T_{j}}$

if: $\xi_{i} \neq \xi_{j}: r_{i j}=\frac{8 \sqrt{\xi_{i} \xi_{j}}\left(\xi_{i}+\rho_{i j} \xi_{j}\right) \rho_{i j}^{3 / 2}}{\left(1-\rho_{i j}^{2}\right)^{2}+4 \xi_{i} \xi_{j} \rho_{i j}\left(1+\rho_{i j}^{2}\right)+4\left(\xi_{i}^{2}+\xi_{j}^{2}\right) \rho_{i j}^{2}}$

$\xi_{1}, \xi_{j}$ are viscous damping ratios that are related to modes $\mathrm{i}, \mathrm{j}$ and $\rho_{i}=\left(T_{\mathrm{i}} / T_{j}\right)$.

Combinations of effects made by seismic action components in three perpendicular directions $(x, y, z)$ are the same as in EN 1998-1:2004.

\subsection{The displacement-based approach}

\subsubsection{Nonlinear static pushover analysis}

Considerable attention and various application possibilities have been given to the nonlinear static method in the second-generation EN 1998-1-1. This is evidenced by detailed presentation of this method in the main text of EN 1998-1-1 (not in the Annex only). The method is based on the pushover analysis and, in the current EN 1998-1:2004, it is explained in Annex B at the end of the main text, and it has very rarely been implemented in practice. This method is the result of scientific research conducted at the University of Ljubljana [12] and is based on the N2 method [13].

The use of nonlinear static method is obligatory in many cases, especially because the concept with $q$ factor, despite being kept in the second generation of this standard, is still highly questionable. In order to conduct nonlinear static analysis, it is first of all necessary to assume cross sections and the quantity of reinforcement, and the result will be expressed as deformations (displacements and relative displacements), i.e. damage to structure (plasticization of some cross sections). In linear calculation methods, reinforcement is obtained as the end result. The nonlinear static analysis according to the second-generation EN 1998-1-1 is used in all cases, i.e. even when there are no influences of higher modes, but also in cases when such influences are present. If the influences exist, then correction factors are applied [13]. 
It can be stated that the use of nonlinear static method is recommended i.e. designers are encouraged to use this method. The reason for this lies in the real nonlinear behaviour of the structure during earthquake and also in the possibility of taking into account the influence of higher modes by means of the nonlinear static method N2 [12,13].

Nonlinear static method and numerical examples are presented in [9]. The N2 method introduces two structure models, and a nonlinear analysis of structures. This method, based on calculation by pushover and an equivalent model with one degree of freedom, can be used for verification of new structures or for estimating bearing capacity of the existing or subsequently strengthened structures of buildings. EN 1998-1-1 provides instructions for pushover analysis, including also the assumed shape of displacement and selection of the displacement control node (target displacement). Instruction for defining an equivalent system with one degree of freedom is also given.

Target displacement is determined from the elastic response spectrum. Target displacement of the control node of a real structure (MDOF) is increased via correction factors, which take into account the effects of higher modes as well as torsional effects (if necessary). These correction factors [13] are a novelty in comparison with the currently valid EN 1998-1:2004. In effect, comprehensive scientific research has been made over the past ten years in this area, and the results obtained have been introduced in this second generation EN1998-1-1. The effects of torsion and higher modes (as the basic nonlinear static method takes into account the first mode only) on displacement values obtained by pushover analysis have been scientifically investigated and introduced in EN1998-1-1.

The curve itself, generated via pushover analysis (capacity of the structure), is obtained using an appropriate software.

If the displacement-based approach is applied then the effects obtained by pushover analysis for buildings must be corrected in the following way:

- displacements are multiplied with the correction factor $c_{\rho}$ that takes into account torsional effects,

- the effects of higher modes of seismic action are introduced by multiplying with correction factors $c_{P}$ and $c_{E}$

Here, in the new nonlinear static method, correction factors can be used to immediately take into account the influence of higher modes as well as the influence of torsion, if necessary.

\subsubsection{Nonlinear dynamic time history analysis}

The response of structures in time can be obtained by direct dynamic integration of the differential equation of motion [9], and, at that, the input values are selected as follows:

- The data on accelerations over time are adopted for a selected earthquake. In this respect, one can use either time-history accelerations recorded in real earthquakes, using Strong Motions (SM) accelerographs, or artificially selected accelerations from the available worldwide database, for instance the one given in [14]. The selected time-history accelerations depend on the type of structure for which the analysis should be made, and depend on circumstances related to the location of the building. A special expert report should be prepared for significant buildings in order to define relevant earthquake and its characteristics (accelerations, velocities or displacements over time) for the specific building and its location.

- For each time-history record, the maximum value of seismic action is determined by analysis. At least seven time-history records should be selected, and an average value of the effects of these seven time-history records will be determined. An example that illustrates this procedure is presented in [15].

- In case of a low level of seismicity, the number of time history records is reduced to three, and the least favourable maximum response is considered. Most of the provisions for the use of nonlinear dynamic analysis that are given in the secondgeneration Eurocode are also contained in the existing standard EN 1998-1: 2004.

\section{Concluding comments}

Before entry into power of the second-generation EN 1998-11 and EN 1998-1-2, it will be necessary to make a comparative study of seismic loading using equivalent lateral static actions obtained according to the currently valid spectra and new proposed spectra. This means that, for any reinforced concrete structure, it is currently not known whether such structure will have more or less reinforcement according to new spectra.

Taking into account novelties introduced in the second-generation EN 1998-1-1 and EN 1998-1-2, all software currently in use for the analysis of structures will have to be extended and modified in the sense of the above-mentioned provisions, i.e. as required by the second generation of this standard. This particularly concerns introduction of the nonlinear static method, which is not at all present in software that are currently used in everyday practice (Tower, SCIA, etc.), but rather the linear method of lateral static load and modal analyses are applied. It is necessary to initiate preparation of seismic hazard maps as soon as possible; these maps should be prepared in the way in which they have already been prepared in some countries $[16,17]$.

In the response spectrum of the existing standard EN 1998-1: 2004, only the spectrum value for $\mathrm{T}=0$ (class $A$ soil) is determined in the probabilistic manner, while in the proposed second-generation spectrum, Figure 1, several spectrum points have been determined in the probabilistic way, while other spectrum points are defined deterministically. If UHS (Uniform Hazard Spectrum) spectra are used, that all spectrum points are determined probabilistically. In [18] is presented the latest scientifically founded way of defining seismic load imposed on structures as based on UHS spectra, such as the ones that are already specified in Canadian and the USA regulations. It is to be expected that UHS spectra will be introduced in the thirdgeneration EN 1998-1-1.

\section{Acknowledgement}

The research presented in this paper was sponsored in part by the University of Rijeka, Croatia, as part of Research Project No. uniri-tehnic-18-127. 


\section{REFERENCES}

[1] Fajfar, P.: Razvoj predpisov za potresno odporno gradnji v Sloveniji - Development of seismic codes in Slovenia, Gradbeni vestnik, 66 (2017) 4, pp. 82-96, UDK 006.82:624.042.7(497.4)

[2] Bubnov, S.: Sigurnost građenja od potresa (neke sugestije za izradu novih propisa), Građevinar, 6 (1962) 1, pp. 178-183.

[3] Pravilnik o privremenim tehničkim propisima za građenje u seizmičkim područjima, Sl. list br. 39/64.

[4] Pravilnik o tehničkim normativima za izgradnju objekata visokogradnje u seizmičkim područjima, Sl. list br. 31/81, 49/82, 29/83, 21/88 i 52/90.

[5] Eurokod 8: Projektiranje potresno otpornih konstrukcija 1. dio: Opća pravila, potresna djelovanja i pravila za zgrade (EN 19981:2004 + AC: 2009), HRN EN 1998-1, 2011.

[6] Fajfar, P.: Analysis in seismic provisions for buildings: past, present and future, (The fifth Prof. Nicholas Ambraseys lecture), Bulletin of Earthquake Engineering, 16 (2018) 7, pp. 2567-2608, https://doi. org/10.1007/s10518-017-0290-8

[7] Bisch, P.: Eurocode 8 - Evolution or revolution? ID 12254, 16 ${ }^{\text {th }}$ European conference on Earthquake Engineering, Thessaloniki, Greece, ID 11952, 18-21 June, 2018.

[8] Herak, M., Prevolnik, S.: UHS ili Tip 1 - pitanje je sad, Zbornik Dana Hrvatske komore inženjera građevinarstva, Opatija, 2017.

[9] Čaušević, M.: Dinamika konstrukcija, Potresno inženjerstvo Aerodinamika - Konstrukcijske euronorme, Golden marketing Tehnička knjiga, Drugo dopunjeno izdanje, Zagreb, 2014.
[10] Labbé, P.: Outlines of the revision of the Eurocode 8, Part 1, general clauses, $16^{\text {th }}$ European conference on Earthquake Engineering, Thessaloniki, Greece, ID 11952, 18-21 June, 2018.

[11] 2018 International Building Code, Chapter 16 STRUCTURAL DESIGN, Section 1613: Earthquake loads, USA, 2018.

[12] Fajfar, P.: A Nonlinear Analysis Method for Performance Based Seismic Design, Earthquake Spectra, 16 (2000) 3, 573-592.

[13] Kreslin, M., Fajfar, P.: The extended N2 method considering higher mode effects in both plan and elevation, Bulletin of Earthquake Engineering, 10 (2012) 2, pp. 695-715.

[14] Gelfi, P.: SIMQKE_GR, Programma per la generazione di accelerogrammi arttificiali spettro-compatibili, University of Brescia, Italy, 2007.

[15] Čaušević, M., Mitrović, S.: Comparison between non-linear dynamic and static seismic analysis of structures according to European and US provisions, Bulletin of Earthquake Engineering, 9 (2011) 2, pp. 467-489.

[16] Lee, V.W., Trifunac, M., Bulajić, B.Đ., Manić, M.ı,, Herak, D., Herak, M., Dimov, G.: Seismic Microzoning in Skopje, Macedonia, Soil Dynamics and Earthquake Engineering, 98 (2017), pp. 166-182.

[17] Trifunac, M., Lee, V.W.: Seizmički Hazard u Srbiji, Izgradnja, 71 (2017) 11-12, pp. 357-378.

[18] Čaušević, M., Bulić, M.: Seismic Retrofit of Bridges for Earthquake Resilient Society, Proceedings of the $16^{\text {th }}$ European Conference on Earthquake Engineering, Thessaloniki, Greece Paper No. 10287, June 18-21, 2018. 